\title{
P01.50. Influence of dietary red palm oil on antioxidant status in male Wistar rats
}

\author{
A Ayeleso ${ }^{1 *}$, O Oguntibeju', N Brooks ${ }^{2}$ \\ From International Research Congress on Integrative Medicine and Health 2012 \\ Portland, Oregon, USA. 15-18 May 2012
}

\section{Purpose}

The study was carried out to evaluate the antioxidant status in male rats following the dietary consumption of red palm oil.

\section{Methods}

Male wistar rats were randomly divided into three groups. Group $1(\mathrm{n}=5)$ received no supplementation and served as the control while group $2(n=6)$ and $3(n=6)$ received $2 \mathrm{ml}$ and $4 \mathrm{ml}$ red palm oil (RPO), respectively. Plasma total polyphenols, plasma antioxidant capacity [i. e. oxygen radical absorbance capacity (ORAC)], ferric reducing antioxidant power (FRAP) as well as levels of antioxidant enzymes [catalase (CAT), glutathione peroxidase (GPx) and superoxide dismutase (SOD)] were determined using established techniques.

\section{Results}

There were no significant differences $(\mathrm{p}<0.05)$ in total polyphenols, ORAC, and FRAP in palm oil fed groups when compared with the control group. Catalase levels significantly increased $(\mathrm{p}<0.05)$ at both $2 \mathrm{ml}$ and $4 \mathrm{ml}$ RPO in the liver and erythrocyte. There was no significant difference in the liver GPx levels in palm oil fed groups while erythrocyte GPx level significantly increased at $4 \mathrm{ml}$ RPO when compared with the control group. Red palm oil did not significantly increase $(\mathrm{p}<0.05)$ liver and erythrocyte SOD levels in all the groups when compared with the control group.

\section{Conclusion}

Red palm oil did not significantly increase the total antioxidant capacity in the plasma. However, RPO significantly increased the levels of liver and erythrocyte

${ }^{1}$ Cape Peninsula University of Technology, Dept of Biomedical Sciences, Bellville, South Africa

Full list of author information is available at the end of the article catalase as well as erythrocyte glutathione peroxidase level and hence, its dietary consumption could help to boost antioxidant status in the body and thus promote good health.

\section{Author details}

${ }^{1}$ Cape Peninsula University of Technology, Dept of Biomedical Sciences, Bellville, South Africa. ${ }^{2}$ Dept of Wellness Sciences, Cape Peninsula University of Technology, Cape Town, South Africa.

Published: 12 June 2012

doi:10.1186/1472-6882-12-S1-P50

Cite this article as: Ayeleso et al:: P01.50. Influence of dietary red palm oil on antioxidant status in male Wistar rats. BMC Complementary and Alternative Medicine 2012 12(Suppl 1):P50.
Submit your next manuscript to BioMed Central and take full advantage of:

- Convenient online submission

- Thorough peer review

- No space constraints or color figure charges

- Immediate publication on acceptance

- Inclusion in PubMed, CAS, Scopus and Google Scholar

- Research which is freely available for redistribution
() Biomed Central
C Biomed Central

(c) 2012 Ayeleso et al; licensee BioMed Central Ltd. This is an Open Access article distributed under the terms of the Creative Commons Attribution License (http://creativecommons.org/licenses/by/2.0), which permits unrestricted use, distribution, and reproduction in any medium, provided the original work is properly cited. 